\title{
Prenatal prediction of osteogenesis imperfecta (OI type IV): exclusion of inheritance using a collagen gene probe
}

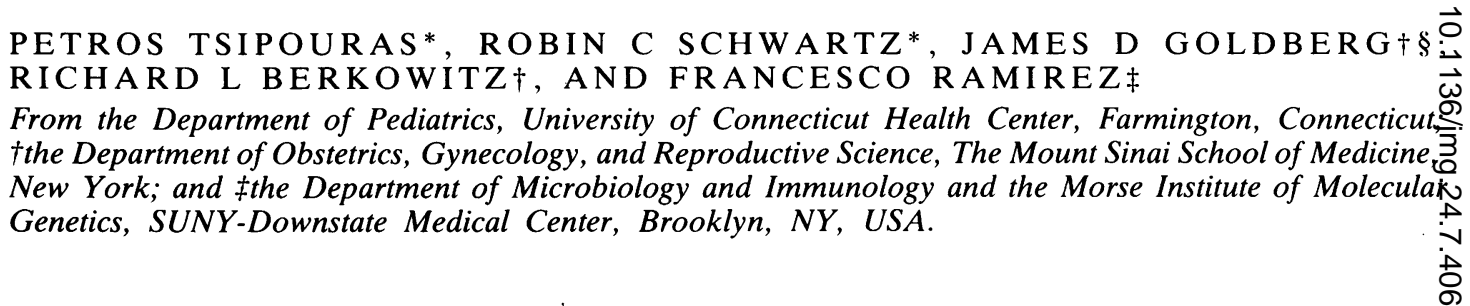

SUMmARY Autosomal dominant osteogenesis imperfecta is caused by mutations in the COL1AZ्ठ and COL1A1 genes of type I collagen. In a family with OI type IV genetically linked to the COL1A2 gene, we attempted prenatal diagnosis in a pregnancy at risk by genotyping the DNA oE the fetus for a COL1A2 gene associated RFLP. Our results showed that the fetus inherited the normal COL1A2 allele from her affected parent. Linkage analysis can thus be used in the्e prenatal diagnosis of dominantly inherited osteogenesis imperfecta.

Genetic linkage studies with DNA markers have been extensively used in the prenatal diagnosis of various hereditary disorders. ${ }^{1-3}$ Osteogenesis imperfecta (OI) is a group of genetic disorders of the connective tissue. Owing to its heterogeneity at least four clinical groups have been identified. ${ }^{4}$ OI type IV is transmitted as an autosomal dominant trait and it is characterised by postnatal onset of fractures, mild to moderate skeletal deformity, joint laxity, and in some families dentinogenesis imperfecta. Tsipouras $e t a l^{56}$ used COL1A2 gene associated RFLPs as markers to show genetic linkage of OI type IV to mutations in the COL1A2 gene. We recently had the opportunity to monitor a pregnancy at risk for OI type IV. Genetic linkage of the OI phenotype to the CCL1A2 RFLPs had been previously established in the family. ${ }^{67}$ Genotypic analysis of DNA from the fetus showed that she had received the normal allele from her affected parent. Furthermore the segregation of the COL1A1 was discordant to the inheritance of the OI phenotype in the family. This study represents the first example of prenatal prediction using genetic linkage studies in a heritable connective tissue disorder. It should be noted that although postnatal diagnosis is not yet

§Present address: Department of Obstetrics-Gynecology, University of California. San Francisco, USA

Received for publication 22 December 1986 Revised version accepted for publication 31 March 1987 confirmed, to date the child at 10 months hao sustained no fractures, suggesting successful preक्ष natal diagnosis.

\section{Methods}

\section{SUBJECTS}

Affected and unaffected subjects from a family wit autosomal dominant OI were studied with one of the several RFLPs associated with the human COL1A2 genes.

CHORIONIC VILLUS SAMPLING

Chorionic villus sampling was performed by trans\$ cervical aspiration under ultrasound guidance using. a 26 gauge Portex (Portex Inc, Wilmington, Massa chusetts) catheter. The sample was immediately examined under a low power dissecting microscope to determine its adequacy. Any adherent maternab decidua were dissected free from the sample and the remaining chorionic villi were used for analysis and plated for cell culture. Informed consent for the procedure and the genotypic analysis of the samples was obtained according to institutional guidelines.

RESTRICTION ENDONUCLEASE ANALYSIS GENOMIC DNA

Nuclear DNA was isolated from the fetal chorionte 
villus tissue and from the leucocytes contained in 10 to $15 \mathrm{ml}$ of EDTA anticoagulated blood according to standard procedures. ${ }^{78}$ DNA (10 to $15 \mu \mathrm{g}$ ) was digested to completion under conditions recommended by the commercial supplier. Digested DNA and DNA size markers were separated by electrophoresis in $0.6 \%$ or $1 \%(\mathrm{w} / \mathrm{v})$ agarose gels. The DNA fragments were transferred to nitrocellulose filters ${ }^{9}$ and hybridised with the human COL1A 2 and COL1A1 probes for 24 to 48 hours as described. The filters were then washed for 10 minutes at $68^{\circ} \mathrm{C}$ with each of the following solutions: $2 \times$ SSC, $1 \times$ SSC, $0.5 \times$ SSC, $0.25 \times$ SSC, and $0.1 \times$ SSC $($ SSC, buffer containing $0.15 \mathrm{~mol} / \mathrm{l} \mathrm{NaCl}$ in $0.015 \mathrm{~mol} / \mathrm{l}$ sodium citrate, $\mathrm{pH} \mathrm{6)}$. The probes used in these experiments were labelled to a specific activity of 2 to $5 \times 10^{8} \mathrm{cpm} / \mu \mathrm{g}$ by nick translation.

DNA PROBES FOR THE HUMAN COLIA2 AND COL1A1 GENES

The cDNA COL1A2 probe used in these experiments has been previously described. ${ }^{10}$ This $2 \cdot 2 \mathrm{~kb}$ cDNA contains sequences complementary to the coding regions of the $3^{\prime}$ half of the human COL1A2 gene including 1443 nucleotides coding for the C-propeptide region and part of the non-coding region of the corresponding mRNA. The genomic DNA COL1A 1 probe is a $2.6 \mathrm{~kb}$ fragment towards the $5^{\prime}$ end of the gene. ${ }^{11}$

\section{LINKAGE ANALYSIS}

The computer programme LINKAGE ${ }^{12}$ was used for calculation of lod scores.

\section{Results}

CASE REPORT

The consultand II. 2 (figure) is a 31 year old G2 P1 Abl female with osteogenesis imperfecta. During her life time she sustained approximately 40 frac-

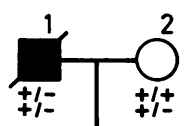

II
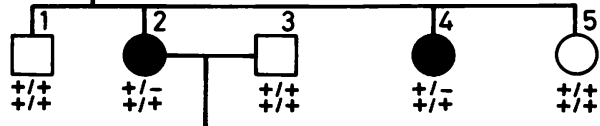

III

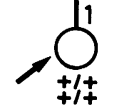

FIGURE Family with OI type IV. The upper + and - refer to the Rsal COLIA2 RFLP. The lower + and refer to the Rsal COLIAI RFLP. Shaded symbols indicate affected with $O I$. tures, with the first occurring at the age of three. Her height was $141 \mathrm{~cm}(<3$ rd centile), weight $40 \cdot 3$ $\mathrm{kg}(<3 \mathrm{rd}$ centile), and head circumference $55 \mathrm{~cm}$ (50th centile). She presented no deformities of the upper or lower extremities. Other physical findings included triangular facies, mild pectus carinatum, and small joint laxity. Her sclerae were grey. No clinical or radiological signs of dentinogenesis imperfecta were observed. Her first pregnancy resulted in miscarriage at approximately eight weeks. During her second pregnancy chorionic villus sampling was performed at eight weeks and genotype analysis showed the fetus to have received the normal COL1A2 allele from her affected parent. Ultrasound examinations performed at 16,28 , and 32 weeks' of gestation showed the fetal skeleton to be normal. The second pregnancy was complicated by premature labour at 28 weeks' gestation, controlled by intravenous ritodrine followed by oral ritodrine until 32 weeks' gestation. At that time the patient experienced recurrence of uterine contractions requiring both intravenous ritodrine and magnesium sulphate for tocolysis. At 33.5 weeks of gestation an amniocentesis was performed which revealed fetal pulmonary maturity. The proband underwent a primary caesarean section under spinal anaesthesia without complications. A $2100 \mathrm{~g}$ (50th centile) female infant, with Apgar scores of 8 and 9 at one and five minutes respectively, was delivered. The infant had no clinical evidence of skeletal deformities or fractures and a gestational age of 32 to 34 weeks by Dubowitz evaluation. The head circumference at birth was $32 \mathrm{~cm}$ (50th centile) and the length was $43 \mathrm{~cm}$ (10th to 59th centile). At four months her length was $63 \mathrm{~cm}$ (50th centile), weight $5.9 \mathrm{~kg}$ (25th centile), and head circumference 42.5 $\mathrm{cm}$ (75th centile). Her psychomotor development was appropriate for age.

LINKAGE ANALYSIS

The genotypic analysis of the family with an EcoRI COL1A2 associated RFLP has been previously reported. ${ }^{67}$ The analysis was suggestive of linkage of the OI phenotype to the COL1A2 gene RFLP. In our present studies we genotyped the family with a new RsaI COL1A2 associated RFLP. ${ }^{13}$ Affected subjects II. 2 and II.4 (figure) were heterozygous for the marker $(+/-)$ while their normal sibs II.1 and II.5 were homozygous $(+/+)$. Since I.1 was also heterozygous while his normal spouse was homozygous, it is obvious that subjects II.2 and II.4 inherited the - allele from their father as well as osteogenesis imperfecta. No recombinants were detected in four informative meioses $(\hat{Z}=0.90$ at $\hat{\theta}=0 \cdot 00$ ). The normal spouse of II. 2 was also homozygous for the RFLP, so the genotyping of 
their offspring will always be informative. Subject III.1 is homozygous $(+/+)$ as shown both in DNA extracted from chorionic villus tissue and cord blood leucocytes. Since the OI phenotype in this family cosegregated with the - allele we concluded that III. 3 had inherited the + allele from her mother and not the one cosegregating with OI. The subsequent genotypic analysis of the family with an RsaI COL1A1 associated RFLP ${ }^{11}$ showed discordant segregation of the marker and the OI phenotype. All four sibs (II.1, II.2, II.4, and II.5) inherited the + allele from their affected parent (I.1) but only II.2 and II.4 also inherited OI (figure).

\section{Discussion}

The knowledge of the genetic distance between two points on the human genome has been exploited, both to define the heterogeneity of hereditary disorders and to offer prenatal diagnosis in some. ${ }^{1-3}$ Genetic distances between various disease and marker loci have been established in almost all 22 autosomes and the $\mathrm{X}$ chromosome. ${ }^{14}$ Lately, a new category of markers has been used in genetic linkage studies, the restriction fragment length polymorphisms associated with known genes or anonymous DNA fragments. ${ }^{14}$

Osteogenesis imperfecta is a heterogeneous group of genetic disorders of the connective tissues, in which defects in type I procollagen have been shown. ${ }^{15-17}$ Using RFLPs associated with the COL1A2 gene, located on chromosome 7 , we showed that a particular phenotypic subgroup of dominantly inherited OI (OI type IV) is genetically linked to the COL1A2 gene.$^{5-7}$ Biochemical studies in cultured skin fibroblasts from affected subjects in one of the families genetically linked to the COL1A2 gene showed a defect in the pro $\alpha 2(\mathrm{I})$ chain, ${ }^{18}$ a finding corroborated by the study of other mutants. ${ }^{19}$ Sykes et al ${ }^{11}$ also showed that autosomal dominant OI (OI types I and IV) is genetically linked to both the COL1A1 and COL1A2 genes. Establishing concordance to one of the two type I collagen structural gene loci and discordance to the other provides a unique approach for prenatal diagnosis in pregnancies at risk. In the case we reported here, the cosegregation of a COL1A2 gene associated RFLP and the OI phenotype was established before the pregnancy. Since the RFLP genotypes of the two parents would always yield information about the affection status of the fetus, we attempted the genotyping of the DNA of the fetus. The analysis of our results showed that the fetus received the normal COL1A2 allele from her affected parent, a result confirmed postnatally.
Since the RFLP used in our studies is within the COL1A2 gene, the possibility of recombination between the marker and the mutation site is highly? unlikely. Our assumption about genetic linkage of the OI phenotype to the COL1A2 gene in this particular family was based on the following: (1) the previous demonstration of genetic linkage of $O P$ type IV to the COL1A2 gene, ${ }^{5-7} 11$ and (2) thes exclusion of a major third locus as the site of mutations resulting in OI, strongly suggested by thefindings of Sykes et al. ${ }^{11}$ A larger sample of familiesw with dominantly inherited OI, genotyped for the type I collagen genes, is needed in order to establish at a $95 \%$ confidence limit the absence of a third locus associated with OI. ${ }^{11}{ }^{20}$

The phenotype of dominantly inherited OI (OL types I and IV) is not always expressed at birth. ${ }^{4}$ In the case we report here, the proband had not sustained any fractures up to the age of 10 months and, most importantly, her linear growth has beere consistently normal ( $\mathrm{R}$ Dreifuss, personak communication, 1987), an indirect sign of not being -0 affected with OI. ${ }^{4}$

Prenatal diagnosis of osteogenesis imperfecta has been previously performed in the lethal perinatab type of this disorder (OI type II) by ultrasound scanning and biochemical studies. ${ }^{21}{ }^{22}$ The sensitivity of either of the two previously mentioned methods is insufficient and therefore unacceptable 0 in the prenatal diagnosis of the mild dominantly $\overrightarrow{0}$ inherited OI. Since only 7 to $28 \%$ of subjects with this type of OI are born with fractures, ${ }^{423}$ fre? quently resulting from trauma at birth, ultrasound scanning will give a high number of false negative results. Furthermore the biochemical characterisa 6 tion of individual OI mutations is attainable in onlyg a small fraction of families with mild dominantly. inherited OI, thus making this type of prenatap diagnosis untenable. Genetic linkage studies there fore offer a valid alternative for prenatal detections in this group of genetic disorders of the connectives tissue in informative families.

The authors thank family $\mathrm{C}$ for their cooperation and Drs Bryan Sykes and Richard Gelinas for gifts of the COL1A1 gene probes. This study was $\omega$ supported in part by research grant AR-38648 from the National Institutes of Health and by the Marche of Dimes 6-411 and 1-1042. Dr Tsipouras is the recipient of a Clinical Investigator Award AR-01224. of the NIH.

\footnotetext{
References

1 Woo SLC, Lidsky AS, Güttler F, Chandra T, Robson KJH. 을 Cloned human phenylalanine hydroxylase gene allows prenatak
} 
diagnosis and carrier detection of classical phenylketonuria. Nature 1983;306:151-5.

2 Kazazian HH, Phillips JA III, Boehm CD, Vik TA, Mahoney MJ, Ritchey AK. Prenatal diagnosis of $\beta$-thalassemias by amniocentesis: linkage analysis using multiple polymorphic restriction endonuclease sites. Blood 1980:56:926-30.

${ }^{3}$ Kidd VJ, Golbus MS, Wallace RB, Itakura K. Woo SLC. Prenatal diagnosis of $\alpha 1$-antitrypsin deficiency by direct analysis of the mutation site in the gene. N Engl J Med 1984;310:639-42.

${ }^{4}$ Sillence DO, Senn A. Danks DM. Genetic heterogencity in osteogenesis imperfecta. J Med Genet 1979;16:101-16.

5 Tsipouras P, Myers JC, Ramirez F, Prockop DJ. Restriction fragment length polymorphism associated with the proa2(I) gene of human type I procollagen. J Clin Invest 1983:72:1262-7.

6 Tsipouras P, Børresen AL, Dickson LA, Berg K, Prockop DJ, Ramirez F. Molecular heterogeneity in the mild autosomal dominant forms of osteogenesis imperfecta. Am J Hum Genet 1984;36:1172-9.

${ }^{7}$ Falk CT, Schwartz RC, Ramirez F, Tsipouras P. Use of molecular haplotypes specific for the human proa2(I) collagen gene in linkage analysis of the mild autosomal dominant forms of osteogenesis imperfecta. Am J Hum Genet 1986;38:269-79.

* Gosden JR, Mitchell AR, Gosden CM, Rodeck CH, Morsman JM. Direct vision chorion biopsy and chromosome-specific DNA probes for determination of fetal sex in first trimester prenatal diagnosis. Lancet 1982;ii:1416-9.

${ }^{y}$ Southern EM. Detection of specific sequences among DNA fragments separated by gel electrophoresis. J Mol Biol 1975:98:503-17.

${ }^{10}$ Myers JC, Chu ML, Faro SH, Clark WJ, Prockop DJ, Ramirez F. Cloning a cDNA for the proa 2 chain of human type I collagen. Proc Natl Acad Sci USA 1981;78:3516-20.

"Sykes B, Ogilvie D, Wordsworth P, Anderson J, Jones N. Osteogenesis imperfecta is linked to both type I collagen structural genes. Lancet 1986;ii:69-72.

12 Lathrop M, Lalouel JM, Fullier C. Ott J. Strategies for multilocus linkage analysis in humans. Proc Natl Acad Sci USA 1984;81:3443-6.

13 Grobler-Rabie AF, Wallis G, Brebner DK, Beighton P, Bester AJ, Mathew CG. Detection of a high frequency Rsal poly- morphism in the human proa2(I) collagen gene which is linked to an autosomal dominant form of osteogenesis imperfecta. EMBO J 1985:4:1745-8.

14 Eighth International Workshop on Human Gene Mapping. Cytogenet Cell Genet 1985:40:1-824.

15 Dickson LA. Pihlajaniemi T, Deak SB, et al. Nuclease S1 mapping of a homozygous mutation in the carboxypeptidecoding region of the proa2(I) collagen gene in a patient with osteogenesis imperfecta. Proc Natl Acad Sci USA 1984; 81:4524-8.

${ }^{16}$ Chu ML, Williams CJ, Pepe G, Hirsch JL, Prockop DJ, Ramirez F. Internal deletion in a collagen gene in a perinatal lethal form of osteogenesis imperfecta. Nature 1983;304:78-80.

17 Barsh GS, David K. Byers PH. Type I osteogenesis imperfecta, a non-functional allele for proal(I) chains of type I collagen. Proc Natl Acad Sci USA 1982;79:3838-42.

${ }^{18}$ Wenstrup RJ, Tsipouras P, Byers PH. Osteogenesis imperfecta type IV: confirmation of linkage to the proa2(I) gene of type I collagen. J Clin Invest 1986;78:1449-55.

19 Wenstrup RJ, Hunter A, Byers PH. Osteogenesis imperfecta type IV; evidence of abnormal triple helical structure of type I collagen. Hum Genet 1986:74:47-53.

$20 \mathrm{Ott} \mathrm{J}$. The number of families required to detect or exclude linkage heterogeneity. Am J Hum Genet 1986;39:159-65.

${ }^{21}$ Shapiro JE, Phillips JA III. Byers PH, et al. Prenatal diagnosis of lethal perinatal osteogenesis imperfecta (OI type II). $J$ Pediatr 1982;100:117-33.

22 Elejalde BR. Elejalde MM. Prenatal diagnosis of perinatally lethal osteogenesis imperfecta. Am J Med Genet 1983;14:353-9.

23 Paterson CR. McAllion S, Miller R. Osteogenesis imperfecta with dominant inheritance and normal sclerac. $J$ Bone Joint Surg(Br) 1983;65:35-9.

Correspondence and requests for reprints to $\mathrm{Dr}$ Petros Tsipouras, Division of Human Genetics, Department of Pediatrics, University of Connecticut Health Center, Farmington, Connecticut 06032, USA. 